\title{
AKRUAL
}

Jurnal Akuntansi

http://journal.unesa.ac.id/php.index/aj

\section{PRAKTIK PENGELOLAAN ASET DESA \\ DI PEMERINTAHAN DESA PROVINSI JAWA TENGAH}

\author{
Sutaryo \\ Fakultas Ekonomi, Universitas Sebelas Maret \\ Sutaryo@staff.uns.ac.id \\ Intan Nuwandari \\ Fakultas Ekonomi, Universitas Sebelas Maret \\ intannuwandari@student.uns.ac.id
}

\begin{abstract}
Abstrak
Pengelolaan Keuangan Desa merupakan kegiatan yang meliputi perencanaan, pelaksanaan, penatausahaan, pelaporan, dan pertanggungjawaban keuangan desa.Undangundang Nomor 6 Tahun 2014 tentang Desa, desa memiliki otonomi sendiri untuk mengatur dan mengurus kepentingan masyarakat setempat beserta rumah tangga desa. Kewenangan yang dimiliki oleh desa salah satunya adalah kewenangan dalam pengelolaan aset desa yang ditujukan untuk meningkatkan kesejahteraan masyarakat desa dan meningkatkan pendapatan desa. Pemanfaatan aset desa tentunnya harus sesuai dengan peraturan yang ada dalam Permendagri Nomor 1 Tahun 2016 tentang Pengelolaan Aset Desa.
\end{abstract}

Kata kunci: keuangan desa, dana desa, pemerintahan desa, pengelolaan aset desa

\section{PENDAHULUAN}

Indonesia dengan memiliki wilayah pedesaaan dan perkotaan, bahkan Indonesia yang memiliki wilayah yang cukup luas untuk dibangun dan bergantung dari wilayah pedesaan. Dilihat dari luasnya wilayah Indonesia didominasi oleh pedesaan. Namun jika diperhatikan, masyarakat desa memiliki permasalahan terutama karena masalah ketertertinggalannya dari perkotaan dalam segi pembangunan. Ketinggalan desa disebabkan oleh pola pembangunan yang belum tepat. Beberapa fakta yang terjadi kurang berkembangnya kesempatan kerja dan rendahnya produktivitas kerja di sektor ekonomi pedesaan berdampak mengalirnya tenaga kerja ke wilayah perkotaan. Salah satu penyebab lambannyya tingkat produktivitas tenaga kerja adalah upah rill buruh pertanian yang sedikit. Selain karena kedua faktor tersebut terdapat faktor lainnya yaitu: kurangnya hubungan dengan masyarakat luar, perkembangan IPTEK yang lamban, sikap masyarakat yang tradisional, prasangka terhadap hal-hal yang baru, adat atau kebiasaan, ketergantungan, rasa tidak percaya diri, rasa tidak aman dan regresi, kelompok kepentingan, SDM yang kurang mendukung, saran dan prasarana yang belum memadai.

Dari aspek luas wilayah, wilayah pemerintahan daerah kabupaten relatif lebih luas daripada wilayah pemerintahan daerah kota. Oleh karenanya, di wilayah kabupaten 
banyak terdapat desa tertinggal, sementara untuk menjangkau pemerataan pembangunan di seluruh wilayah dibutuhkan anggaran yang lebih besar. Dari aspek kependudukan, kepadatan penduduk di kabupaten lebih rendah daripada kota. Dari aspek mata pencaharian penduduk, penduduk kabupaten umumnya bergerak di bidang pertanian atau bersifat agraris. Dari aspek struktur pemerintahan, di wilayah kota dibentuk kecamatan dan kelurahan, sementara di wilayah kabupaten terdapat kecamatan, kelurahan, dan desa atau kampong

Dengan permasalahan yang terjadi maka dibuatlah beberapa peraturan yang mengatur tentang desa. Sejak reformasi berlangsung di Indonesia, inisiatif untuk melakukan pembaharuan desa terus bermunculan. Arah dari demokrasi ini adalah agar praktik demokrasi desa berlangsung dengan baik serta menuju kemandirian dan kesejahteraan warga desa. Pada era reformasi diterbitkannya Undang-undang Nomor 2 tahun 1999 kemudian disempurnakan menjadi Undang-undang Nomor 32 tahun 2004 tentang Pemerintah Daerah hingga saat ini diterbitkannya Undang-undang Nomor 6 tahun 2014 tentang Desa yang mana menegaskan dengan memberikan keleluasaan kepada desa untuk dapat lebih mengatur rumah tangganya sendiri sesuai dengan kodisi adat budaya setempat. Selanjutnya undang-undang tersebut dipertegas dalam Peraturan Pemerintahan Nomor 43 tahun 2014 dan diperbarui dengan Peraturan Pemerintahan Nomor 47 tahun 2015 yang memuat tentang peraturan pelaksanaan undang-undang desa tersebut. Setiap desa pastinya memiliki aset aset desa, oleh karena itu untuk megatur pengelolaan aset desa tersebut dibuatlah Peraturan Menteri Dalam Negeri Nomor 1 tahun 2016 tentang pengelolaan aset desa.

Penetapan Undang-undang Nomor 6 tahun 2014 tentang Desa selaras dengan tujuan otonomi daerah yang memberikan kewenangan kepada setiap daerah untuk mengurus dan mengatur semua urusan pemerintahan serta menciptakan upaya kemandirian daerah dengan potensi yang dimilikinya. Rencana pemerintah yang mengucurkan anggran 1,4 miliar tiap desa setiap tahunnya menimbulkan kekhawatiran pada efektivitas dan transparansi berbagai pihak dalam penggunaannya. Pasalnya terdapat sejumlah permasalahan yang ditemukan dalam pengawasan yang dilakukkan pada desa. Dimana banyak desa belum benar-benar siap untuk menerapkan Undangundang Desa tersebut.

Undang-undang desa tentunya dibuat agar fungsi desa dapat berjalan sesuai dengan tujuan yang telah diharapkan. Aset desa dapat digunakan sebagai tambahan pendapatan desa. Namun, dalam praktiknya sering terjadi permasalahan dalam pengelolaaan aset 
desa. Tidak maksimalnya pemanfaatan aset yang dimiliki desa dan penyelewengan yang dilakukan oknum pemerintah desa sering menjadi sebab permasalahan yang terjadi. Oleh sebab itu, dibuatlah Undang-undang yang mengatur tentang pengelolaan kekayaan desa yang diperjelas dengan Permendagri tentang aset desa. Tujuan paper ini adalah untuk mengetahui bagaimana persepsi aparatur desa dan inspektorat daerah mengenai pengelolaan aset desa di pemerintahan desa Provinsi Jawa Tengah. Hasil penelitian dapat digunakan sebagai bahan evaluasi terhadap implementasi Permendagri/1/2016 tentang aset desa. Hasil penelitian yang dilaksanakan oleh penulis yaitu memberikan informasi kebijakan terkait aset desa. Hasil penelitian yang dilaksanakan oleh penulis dapat digunakan sebagai bahan referensi untuk penelitian selanjutnya terutama terkait dengan akuntansi pemerintahan khususnya mengenai aset desa.

\section{TINJUAN PUSTAKA}

\section{Desentralisasi dan Otonomi Daerah}

UU/32/2004 merupakan Undang-undang yang mengatur Tentang Pemerintah Daerah. Definisi pemerintah daerah berdasarkan UU/32/2004 yaitu pemerintah daerah merupakan penyelenggara urusan pemerintahan oleh pemerintah daerah dan DPRD menurut asas otonomi dan tugas pembantu dengan perinsip otonomi yang seluas-luasya dalam sistem dan perinsip Negara Kesatuan Republik Indonesia sebagaimana dimaksud dalam Undangundang dasar Republik Indonesia. Menurut UU/32/2004, desentralisasi adalah penyerahan wewenang pemerintahan oleh pemerintah kepada daerah otonom untuk mengatur dan mengurus urusan pemerintahan dalam sistem Negara Kesatuan Republik Indonesia.

Otonomi daerah menurut UU/32/2004 adalah hak, wewenang dan kewajiban daerah otonom untuk mengatur dan mengurus sendiri urusan pemerintahan dan kepentingan masyarakat setempat sesuai dengan peraturan perundang-undangan. Sedangkan menurut Bastian (2002) otonomi daerah merupakan upaya pemberdayaan daerah dalam pengambilan keputusan daerah secara lebih leluasa untuk mengelola sumberdaya yang dimilikinya sesuai dengan kepentingan, proritas, dan potensi daerah sendiri.

\section{Pemerintahan Desa}

Kemampuan untuk mengurusi urusan desa dan kemandirian desa dibuktikan dengan tidak lagi bergantung kepada pemerintahan yang lebih tinggi desa. Konsep Otonomi Desa tentu 
saja harus memeperhatikan latar belakang peerkembangan desa. UU/32/2004 dijadikan dasar terhadap perkembang desa. Untuk implementasi desa yang mandiri diperlukan konsekuensi penyerahan kewenangan desa (desentarlisasi). Dengan demikian, diaturlah Undang-undang mengenai Desa, yang diatur dalam UU/6/2014. Menurut undang-undang ini desa adalah desa dan desa adat atau yang disebut dengan nama lain, selanjutnya disebut desa, adalah kesatuan masyarakat hukum yang memiliki batas wilayah yang berwenang untuk mengatur dan mengurus urusan pemerintahan, kepentingan masyarakat setempat berdasarkan prakarsa masyarakat, hak asal usul, dan hak tradisional yang diakui dan dihormati dalam sistem pemerintahan Negara Kesatuan Republik Indonesia.

Menurut UU/6/2014, Pemerintah Desa adalah penyelenggara urusan pemerintahan dan kepentingan masyarakat setempat dalam sistem pemerintahan Negara Kesatuan Republik Indonesia. Penyelenggaraan Pemerintahan desa, pelaksanaan pembangunan Desa, pembinaan kemasyarakatan Desa, dan pemberdayaan masyarakat Desa berdasarkan Pancasila, Undang-undang Negara Republik Indonesia Tajhun 1945, Negara Kesatuan Republik Indonesia, dan Bhineka Tunggal Ika.

\section{Pengelolaan Keuangan Desa}

Pengelolaan keuangan desa diataur dalam Permendagri/113/2014 tentang Pengelolaan Keuangan Desa. Keuangan desa dikelola berdasarkan asas-asas transparan, akuntabel, partisipatif serta dilakukan dengan tertib dan disiplin anggaran. Sekretaris Desa menyusun Rancangan Peraturan Desa tentang APBDesa berdasarkan RKPDesa tahun berkenaan dan menyampaikan rancangan Peraturan Desa tentang APBDesa kepada Kepala Desa. Rancangan Peraturan Desa tentang APBDesa disepakati bersama paling lambat bulan Oktober tahun berjalan. Rancangan Peraturan Desa tentang APBDesa yang telah disepakati disampaikan oleh Kepala Desa kepada Bupati/Walikota melalui camat atau sebutan lain paling lambat 3 (tiga) hari sejak disepakati untuk dievaluasi. Bupati atauWalikota menetapkan hasil evaluasi Rancangan APBDesa paling lama 20 (dua puluh) hari kerja sejak diterimanya Rancangan Peraturan Desa tentang APBDesa. Bupati atau Walikota menyatakan hasil evaluasi Rancanga Peraturan Desa tentang APBDesa tidak sesuai dengan kepentingan umum dan peraturan perundang-undangan yang lebih tinggi, Kepala Desa melakukan penyempurnaan paling lama 7 (tujuh) hari kerja terhitung sejak diterimanya hasil evaluasi Apabila hasil evaluasi tidak ditindak lanjuti oleh Kepala Desa sebagaimana dan Kepala Desa tetap menetapkan Rancangan Peraturan Desa tentang 
APBDesa menjadi Peraturan Desa, Bupati atauWalikota membatalkan Peraturan Desa dengan Keputusan Bupati atau Walikota.

Semua penerimaan dan pengeluaran desa dalam rangka pelaksanaan kewenangan desa dilaksanakan melalui rekening kas desa. Khusus bagi desa yang belum memiliki pelayanan perbankan di wilayahnya maka pengaturannya ditetapkan oleh Pemerintah Kabupaten atau Kota. Semua penerimaan dan pengeluaran desa harus didukung oleh bukti yang lengkap dan sah. Pemerintah desa dilarang melakukan pungutan sebagai penerimaan desa selain yang ditetapkan dalam peraturan desa.Bendahara dapat menyimpan uang dalam Kas Desa pada jumlah tertentu dalam rangka memenuhi kebutuhan operasional pemerintah desa. Pengaturan jumlah uang dalam kas desa ditetapkan dalam Peraturan Bupati/Walikota. Pengeluaran desa yang mengakibatkan beban APBDesa tidak dapat dilakukan sebelum rancangan peraturan desa tentang APBDesa ditetapkan menjadi peraturan desa. Pengeluaran desa tidak termasuk untuk belanja pegawai yang bersifat mengikat dan operasional perkantoran yang ditetapkan dalam peraturan kepala desa. Penggunaan biaya tak terduga terlebih dulu harus dibuat Rincian Anggaran Biaya yang telah disahkan oleh Kepala Desa.

\section{Pengelolaaan Aset Desa}

Pengelolaan Aset Desa diatur dalam Permendagri/1/2016. Permendagri ini ditetapkan pada tanggal 7 Januari 2016. Menurut Permendagri/1/2016, Aset Desa adalah barang milik desa yang berasal dari kekayaan asli milik desa, dibeli atau diperoleh atas Anggaran Pendapatan dan Belanja Desa (APBDesa) atau perolehan hak lainnya yang sah. Menurut Permendagri/1/2016, Pengelolaan aset desa adalah merupakan rangkaian kegiatan mulai dari perencanaan, pengadaan, penggunaan, pemanfaatan, pengamanan, pemeliharaan, penghapusan, pemindahtanganan, penatausahaan, pelaporan, penilaian, pembinaan, pengawasan, dan pengendalian aset desa.

Kekayaan asli daerah yang dimaksudkan adalah berupa: tanah kas desa, pasar desa, pasar hewan, tambatan perahu, bangunan desa, pelelangan ikan yang dikelola oleh desa, pelelangan hasil pertanian, hutan milik desa, mata air milik desa, pemandian umum dan lain-lain kekayaan asli desa. Menurut Permendagri/1/2016, pengelolaan aset desa dilaksanakan berdasarkan asas fungsional, kepastian hukum, transparansi dan keterbukaan, efisiensi, akuntanbilitas, dan kepastian nilai.

Otonomi daerah merupakan pondasi dalam penyelenggaraan pemerintah daerah. Otonomi daerah adalah hak, wewenang, dan daerah otonom untuk mengatur dan 
mengurus sendiri urusan pemerintahan dan kepentingan masyarakat setempat sesuai dengan peraturan perundang-undangan. Posisi yang paling dekat dengan masyarakat adalah pemerintah desa. Adapun pengelolaan aset desa meliputi:

\section{Perencanaan}

Perencanan aset desa dituangkan dalam Rencana Pembangunan Jangka Menengah Desa (RPJMDesa) untuk kebutuhan 6 tahun. Selain untuk kebutuhan enam tahun. Terdapat pula perencanaan kebutuhan aset desa untuk yang satu tahun dituangkan dalam Rencana Kerja Pemerintah Desa (RKPDesa) dan ditetapkan dalan APBDesa setelah memperhatikan ketersediaan aset yang ada.

\section{Pengadaan dan Penggunaan}

Pengadaan aset desa didasarkan oleh perinsip-perinsip efisien, efektif, transparan dan terbuka, bersaing, adil atau tidak diskriminatif dan akuntabel. Pengadaan barang atau jasa di desa diatur dengan Peraturan Bupati atau Walikota dengan berpedoman pada ketentuan peraturan perundang-undangan. Penggunaan aset desa ditetapkan dalam rangka mendukung penyelenggaraan Pemerintahan desa. Dan status penggunaan aset desa ditetapkan setiap tahun dengan Keputusan Kepala Desa.

\section{Pemanfaatan.}

Pemanfaatan aset desa dapat dilaksanakan sepanjang tidak dipergunakan langsung untuk menunjang penyelenggaraan pemerintahan desa. Bentuk pemanfaatan berupa: sewa, pinjam pakai, kerjasama pemanfaatan, bangun guna serah atau bangun serah guna. Pemanfaatan aset desa ditetapkan dalam Peratusan Desa. Pemanfaatan aset berupa sewa tidak merubah status kepemilikan dan jangka waktu paling lama adalah tiga tahun namun dapat diperpanjang

Pemanfaatan aset berupa pinjam pakai dilaksanakan antara Pemerintah desa dengan Pemerintah Desa lainnya serta Lembaga kemasyarakatan Desa. Pinjam pakai dikecualikan untuk tanah, bangunan dan aset bergerak berupa kendaraan bermotor.

Kerjasama pemanfaatan berupa tanah atau bangunan dengan pihak lain dilaksanakan dalam rangka mengoptimalkan daya guna dan hasil guna serta meningkatkan pendapatan desa. Kerjasama pemanfaatan aset desa berupa tanah dan bangunan dengan pihak lain dilaksanakan dengan ketentuan: tidak tersedia cukup dana dalam apbdesa untuk memenuhi biaya oprasional, pemeliharaan, dan perbaikan yang 
diperlukan terhadap tanah dan bangunan tersebut; dan pihak lain dilarang meminjamkan atau menggadaikan aset desa yang menjadi objek kerja sama pemanfaatan.

\section{Pemeliharaan}

Pemeliharaan adalah kegiatan yang dilakukan agar semua aset desa selalu dalam keadaan baik dalam rangka penyelenggaraan pemerintahan desa. Pemeliharaan dilakukkan terhadap barang inventaris yang sedang dalam pemakaian, tanpa merubah, menaambah atau mengurangi bentuk, sehingga dapat dicapai pendayagunaan barang yang memenuhi persyaratan dengan baik. Pemeliharaan aset desa wajib dilakukan oleh Kepala Desa dan perangkat desa. Biaya pemeliharaan aset desa dibebankan pada APBDesa.

\section{Penghapusan}

Penghapusan aset desa merupakan kegiatan menghapis atau memindah aset desa dari buku inventaris desa. Penghapusan aset desa terjadi karena: beralih kepemilikan, pemusnahan, hilang, kecurian dan terbakar. Penghapusan aset desa yang beralih kepemilikan, antara lain: Pemindahtanganan atas aset desa kepada pihak lain; putusan pengadilan yang telah berkekuatan hukum tetap. Desa yang kehilangan hak sebagai akibat dari putusan pengadilan, wajib menghapus dari daftar inventaris aset milik desa. Pemusnahan aset desa sebagaimana dimaksud, dengan ketentuan: berupa aset yang sudah tidak dapat dimanfaatkan dan/atau tidak memiliki nilai ekonomis, antara lain meja, kursi, komputer; dan dibuatkan Berita Acara pemusnahan sebagai dasar penetapan keputusan Kepala Desa tentang Pemusnahan.

Penghapusan aset desa yang bersifat strategis terlebih dahulu dibuatkan Berita Acara dan ditetapkan dengan Keputusan Kepala Desa setelah mendapat persetujuan Bupati atau Walikota. Penghapusan aset Desa tidak perlu mendapat persetujuan Bupati atauWalikota namun terlebih dahulu dibuat Berita Acara dan ditetapkan dengan Keputusan Kepala Desa. Aset milik desa yang desa-nya dihapus sebagai dampak pembangunan seperti waduk, uang penggantinya diserahkan kepada pemerintah Kabupaten atau Kota sebagai pendapatan daerah. Aset milik desa-desa yang digabung sebagai dampak pembangunan seperti waduk, uang penggantinya menjadi milik desa. Uang pengganti ini merupakan pendapatan desa yang penggunaannya diprioritaskan untuk pembangunan sarana prasarana desa. Aset milik desa yang desa-nya dihapus atau digabung dalam rangka penataan desa, aset desa yang desa-nya dihapus menjadi milik desa yang digabung. 


\section{Pemindahtanganan}

Bentuk pemindahtanganan aset desa meliputi: tukar menukar, penjualan dan penyertaan modal Pemerintah desa aset desa dapat dijual apabila: aset tidak memiliki nilai manfaat dalam mendukung penyelnggaraan pemerintah desa; aset berupa tanaman tumbuhan dan ternak yang dikelola oleh pemerintah desa seperti: pohon jati, maranti, bambu, sapi dan kambing; penjulan aset dilakukan melalui penjualan langsung atau lelang; penjulan langsung antara lain: meja, kursi, komputer, mesin tik serta tanaman tumbuhan dan ternak; penjualan melalui lelang antara lain: kendaraan bermotor, peralatan mesin; Penjualan melalui lelang dilengkapi dengan bukti penjualan dan ditetapkan dengan keputusan Kepala Desa tentang Penjualan; Uang hasil penjualan dimasukkan dalam rekening kas desa sebagai pendapatan asli desa; Penyertaan modal Pemerintah Desa atas aset desa dilakukan dalam rangka pendirian, pengembangan dan peningkatan kinerja Badan Usaha Milik Desa (BUMDesa). Adapun penyertaan modal yang dimaksudkan adalah berupa Tanah Kas Desa.

\section{Penatausahaan}

Aset desa yang sudah ditetapkan penggunaannya harus diinventarisir dalam buku inventaris aset desa dan diberi kodefikasi. Kodefikasi ini telah diatur dalam pedoman umum mengenai kodefikasi aset desa.

\section{Penilaian}

Penilaian aset dilakukan oleh Pemerintah Kabupaten bersama dengan Pemerintah desa melakukan inventarisasi aset berdasarkan ketentuan perundang-undangan. Penilaian aset desa dalam rangka pemanfaatan dan pemindahtanganan berupa tanah dan bangunan dilakukan oleh penilai Pemerintah atau penilai Publik.

\section{Pembinaan dan Pengawasan}

Menteri melalui Direktur Jenderal Bina Pemerintahan Desa melakukan pembinaan dan pengawasan terhadap pelaksanaan pengelolaan aset desa. Gubenur melakukaan pembinaan dan pengawasan terhadap pengelolaan aset desa. Bupati atau Walikota melakukan pembinaan dan pengawasan pula terhadap pengelolaan aset desa. Dalam melakukan pembinaaan dan pengawasan Bupati atai Walikota melimpahkan kepada Camat. 


\section{Pengawasan Keuangan Desa}

Sesuai Peraturan Presiden Nomor 192 Tahun 2014, Badan Pengawas Keuangan dan Pembangunan telah diberi amanat untuk melakukan pengawalan terhadap akuntabilitas keuangan dan pembangunan nasional. Pengawalan akuntabilitas pegelolaan keuangan desa merupakan implementasi pengawalan prioritas pembangunan nasional. Pengawasan keuangan desa yang dilakukan oleh BPKP bertujuan untuk memastikan ketentuan dan kebijakan dalam mengimplementasikan Undang-undang Desa dapat terlaksana dengan baik. Jika dapat dilaksanakan dengan baik maka pengawalan desa akan mencapai tujuan yang diharapkan yaitu Good Village Governance dengan indikator sebagai berikut: tata kelola keuangan desa yang baik, perencanaan desa yang partisipatif, terintegrasi dan selaras dengan perencanaan daerah, berkurangnnya penyalahgunaan kekuasaaan atau wewenang yang mengakibatkan permasalahan hukum, dan mutu pelayanan kepada masyarakat meningkat.

\section{Gambaran Umum}

Jawa Tengah merupakan sebuah provinsi Indonesia yang terletak di bagian tengah Pulau Jawa. Dengan ibu kotanya adalah Semarang. Provinsi ini di sebelah barat berbatasan dengan Provinsi Jawa Barat, di sebelah selatan Samudra Hindia dan Daerah Istimewa Yogyakarta, Jawa Timur di sebelah timur, dan di sebelah utara adalah Laut Jawa. Jawa tengah memiliki luas wilayahnya $32.548 \mathrm{~km}^{2}$, atau sekitar 28,94\% dari luas pulau Jawa. Provinsi Jawa Tengah juga meliputi Pulau Nusakambangan di sebelah selatan (dekat dengan perbatasan Jawa Barat), serta Kepulauan Karimun Jawa di Laut Jawa.

\section{Gambar 1}

Peta Jawa Tengah

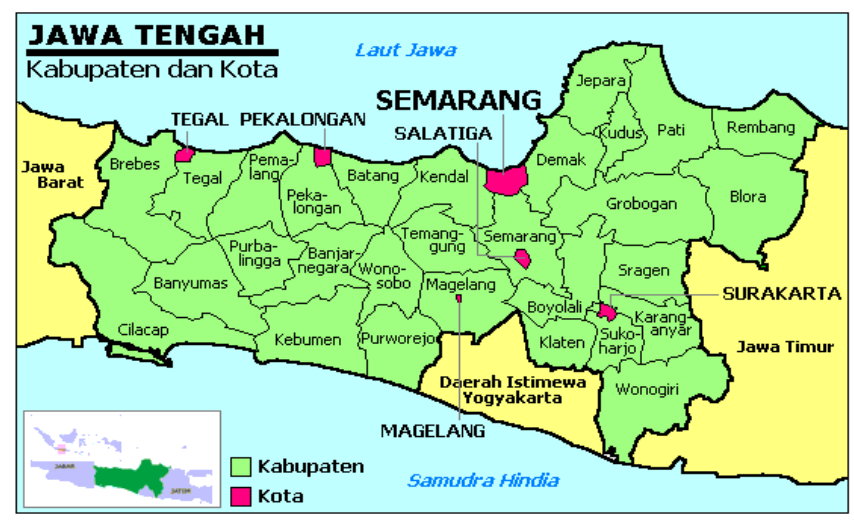

Sumber: https://id.wikipedia.org/wiki/Jawa_Tengah 
Secara administratif, Provinsi Jawa Tengah terdiri atas 29 kabupaten. Administrasi pemerintahan kabupaten ini terdiri atas 545 kecamatan dan 8.490 desa atau kelurahan. Jumlah penduduk Provinsi Jawa Tengah adalah 39.298.765 jiwa terdiri atas 19.281.140 laki-laki dan 19.989.547 perempuan. Pertumbuhan penduduk Provinsi Jawa Tengah sebesar 0,67\% per tahun. Pertumbuhan penduduk tertinggi berada di Kabupaten Demak (1,5\% per tahun), sedang yang terendah adalah Kota Pekalongan (0,09\% per tahun). Dari jumlah penduduk ini, 47\% di antaranya merupakan angkatan kerja. Mata pencaharian paling banyak adalah di sektor pertanian (42,34\%), diikuti dengan perdagangan (20,91\%), industri $(15,71 \%)$, dan jasa (10,98\%).

Jawa Tengah yang memiliki wilayah yang cukup luas untuk dilakukan pembangunan daerah. Dilihat dari luas wilayah, wilayah pemerintahan daerah kabupaten relatif lebih luas daripada wilayah pemerintahan daerah kota. Oleh karenanya, di wilayah kabupaten banyak terdapat desa tertinggal. Sejak reformasi berlangsung di Indonesia, inisiatif untuk melakukan pembaharuan desa terus bermunculan. Dimana arah dari demokrasi ini adalah agar praktik demokrasi desa berlangsung dengan baik serta menuju kemandirian dan kesejahteraan warga desa. Hal yang tepat bersamaan dengan adanya pembangunan desa tertinggal sesuai dengan NAWACITA yang tertuang dalam Perpres Nomor 2 Tahun 2015 tentang RPJMN 2015-2019.

\section{METODE PENELITIAN}

\section{Sampel Penelitian}

Sampel dalam penelitian ini adalah pemerintahan desa yang berada di kabupaten di wilayah Provinsi Jawa Tengah, yang terwakili oleh satu pelaksana sebagai aparatur desa dan pengawas sebagai inspektorat daerah. Jumlah kabupaten yang berada di Provinsi Jawa Tengah adalah sebanyak 29 kabupaten. Dalam penelitian ini, setiap daerah mewakilkan 2 responden yang berarti responden berjumlah menjadi 58 responden. Namun karena keterbatasan akses terdapat 3 kabupaten yang tidak diikutsertakan dan data yang rusak maka responden hanya menjadi 52 responden dengan 26 kabupaten di Provinsi Jawa Tengah. Adapun daftar kabupaten yang menjadi sampel terlampir dalam penelitian ini. 


\section{Data dan Sumber Data}

Sumber data yang digunakan adalah data primer, yaitu data yang diperoleh secara langsung dari responden. Data diperoleh melalaui wawancara dan dengan kuesioner. Kuisioner berisi mengenai definnisi aset desa, perencanaan, pengadaan, penggunaan, pemanfaatan, pengamanan, pemeliharaan, penghapusan, pemindahtanganan, penatausahaan, penilaian, pembinaan, dan pengawasan. Adapun daftar pertanyaan kuesioner terlampir dalam penelitian ini.

\section{ANALISIS DATA}

Deskriptif Analisis, Ghozali (2011) Statistik deskriptif memberikan gambaran atau deskripsi suatu data yang dilihat dari nilai rata-rata (mean), standar devisiasi, nilai minimum, nilai maksimum. Deskriptif Responden dilakukkan untuk menggambarkan responden. Adapun beberapa yang dapat diketahui dalam deskripsi ini antara lain: pendidikan responden, masa jabatan responden, jabatan responden, dan jenis kelamin responden.

\section{Karakteristik Responden}

Tabel di bawah ini menunjukkan daftar pemerintah daerah yang digunakan sebagai sampel penelitian. Terdapat 29 kabupaten di Provinsi jawa Tengah namun tidak semua perwakilan daerah sebagai responden. Dari 52 responden berasal dari Kabupaten Banjarnegara, Banyumas, Blora, Boyolali, Brebes, Cilacap, Demak, Grobogan, Jepara, Karanganyar, Kendal, Temanggung, Wonogiri, Klaten, Kudus, Magelang, Pati, Pekalongan, pemalang, Purworejo, Rembang, Semarang, Sragen, Sukoharjo, Tegal, dan Wonosobo. Terdapat 3 kabupaten yang tidak menjadi responden yaitu berasal dari Kabupaten Batang, Kebumen, dan Purbalingga.

Tabel 1

Daftar Pemerintah Daerah Sebagai Sampel Penelitian

\begin{tabular}{llllllll}
\hline No & Kabupaten & Ya & Tidak & No & Kabupaten & Ya & Tidak \\
\hline 1 & Banjarnegara & $\sqrt{ }$ & & 16 & Klaten & $\sqrt{ }$ & \\
2 & Banyumas & $\sqrt{ }$ & & 17 & Kudus & $\sqrt{ }$ & \\
3 & Batang & & $\sqrt{ }$ & 18 & Magelang & $\sqrt{ }$ & \\
4 & Blora & $\sqrt{ }$ & & 19 & Pati & $\sqrt{ }$ & \\
5 & Boyolali & $\sqrt{ }$ & 20 & Pekalongan & $\sqrt{ }$ & \\
6 & Brebes & $\sqrt{ }$ & 21 & Pemalang & $\sqrt{ }$ & \\
7 & Cilacap & $\sqrt{ }$ & 22 & Purbalingga & & $\sqrt{ }$ \\
\hline
\end{tabular}




\begin{tabular}{|c|c|c|c|c|c|}
\hline 8 & Demak & $\mathrm{V}$ & 23 & Purworejo & $\sqrt{ }$ \\
\hline 9 & Grobogan & $\sqrt{ }$ & 24 & Rembang & $\sqrt{ }$ \\
\hline 10 & Jepara & $\sqrt{ }$ & 25 & Semarang & $\sqrt{ }$ \\
\hline 11 & Karanganyar & $\sqrt{ }$ & 26 & Sragen & $\sqrt{ }$ \\
\hline 12 & Kebumen & $\sqrt{ }$ & 27 & Sukoharjo & $\sqrt{ }$ \\
\hline 13 & Kendal & $\sqrt{ }$ & 28 & Tegal & $\sqrt{ }$ \\
\hline 14 & Temanggung & $\sqrt{ }$ & 29 & Wonosobo & $\sqrt{ }$ \\
\hline 15 & Wonogiri & $\sqrt{ }$ & & & \\
\hline
\end{tabular}

Deskriptif responden dilakukkan untuk menggambarkan karakteristik responden. Adapun beberapa yang dapat diketahui dalam deskripsi ini antara lain: pendidikan responden, masa jabatan responden, jabatan responden, dan jenis kelamin responden. Berikut disajikan karakteristik responden yang terdiri dari 52 responden berasal dari Provinsi Jawa Tengah:

Gambar 2

\section{Karakteristik Pendidikan Responden}

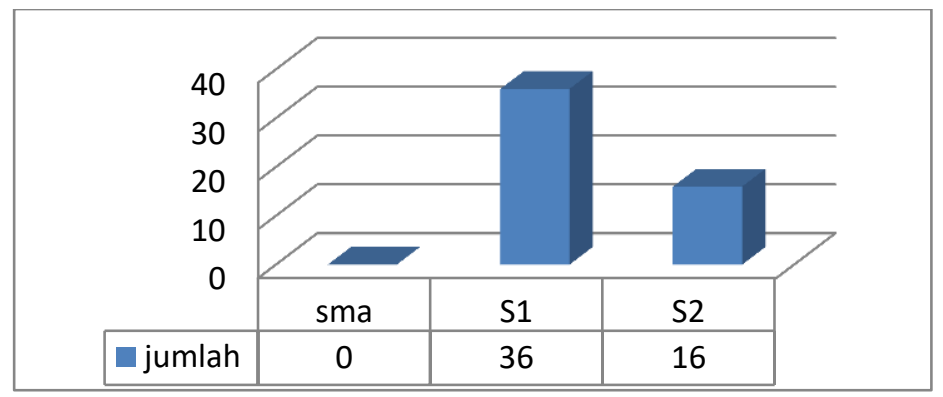

Tabel dan gambar di atas menunjukkan karakteristik pendidikan responden. Dari data tersebut terdapat dua tingkat pendidikan responden yaitu S1 dan S2. Dari total keseluruhan 52 data responden, jumlah responden $\mathrm{S} 1$ adalah sebanyak 36 responden atau sebesar $69,23 \%$. Sedangkan untuk S2 hanya sebanyak 16 reponden dengan persentase sebesar $30,77 \%$. 
Gambar 3

Karakteristik Masa Jabatan Responden

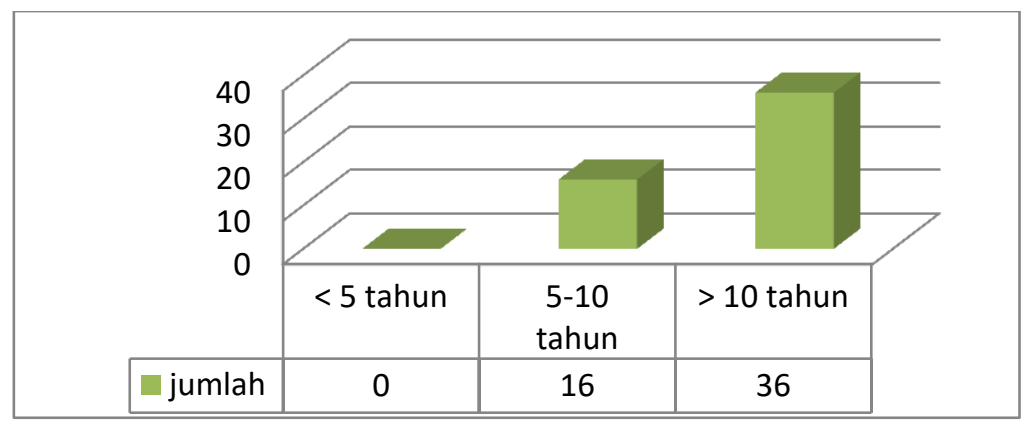

Tabel dan gambar di atas menunjukkan karakteristik masa jabatan responden. Dari data tersebut terdapat tiga masa jabatan responden yaitu kurang dari 5 tahun, antara 5 sampai 10 tahun, dan lebih dari 10 tahun. Dari total keseluruhan 52 data responden, jumlah masa jabatan responden yang kurang dari 5 tahun adalah sebanyak 0 responden atau sebesar $0 \%$. Sedangkan masa jabatan responden antara 5 sampai 10 tahun adalah sebanyak 13 responden dengan persentase sebesar $25 \%$. Sedangkan untuk masa jabatan responden lebih dari 10 tahun adalah sebanyak 39 responden dengan persentase sebesar $75 \%$.

\section{Gambar 4}

\section{Karakteristik Jabatan Responden}

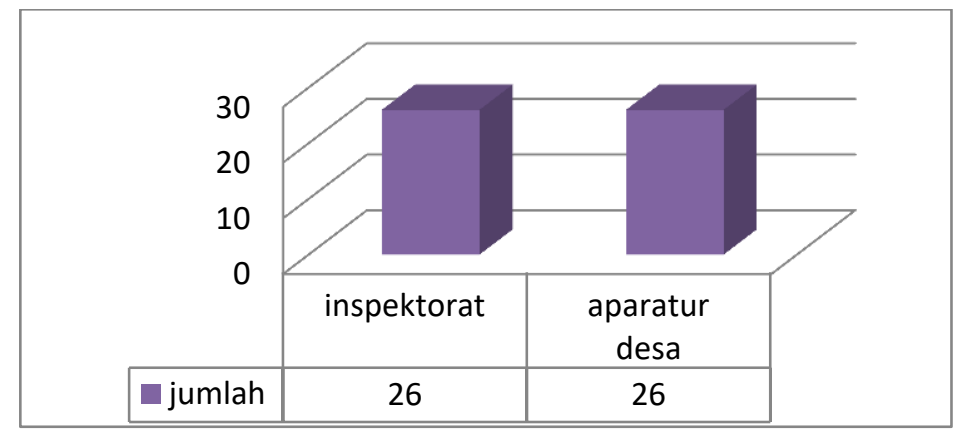

Tabel dan gambar di atas menunjukkan karakteristik jabatan responden. Dari data tersebut digolongkan menjadi dua jabatan responden yaitu inspektorat dan aparatur desa. Dari total keseluruhan 52 data responden, jumlah jabatan responden sebagai inspektorat adalah sebanyak 26 responden atau sebesar $50 \%$. Sedangkan untuk jumlah responden aparatur desa sebanyak sama dengan jumlah jabatan inspektorat yaitu 26 reponden dengan persentase sebesar $50 \%$. 
Gambar 5

Karakteristik Jenis Kelamin Responden

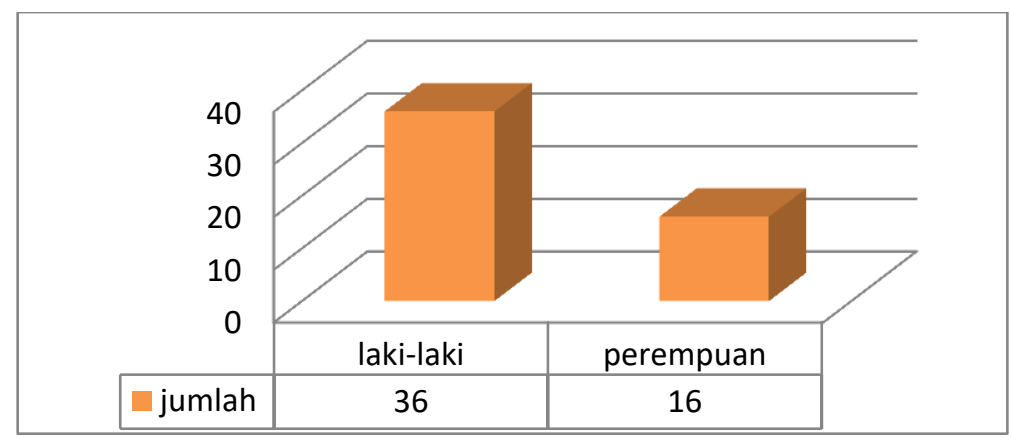

Tabel dan gambar di atas menunjukkan karakteristik dilihat dari jenis kelamin responden. Dari data tersebut dibedakan menjadi dua jenis kelamin responden yaitu lakilaki dan perempuan. Dari total keseluruhan 52 data responden, jumlah responden laki-laki adalah sebanyak 36 responden atau sebesar 69,23\%. Sedangkan jumlah responden perempuan hanya sebanyak 16 responden dengan persentase sebesar $30,77 \%$.

Penelitian yang dilakukkan terhadap 52 responden, yang terdiri dari aparatur desa dan inspektorat. Setiap responden memperoleh pertanyaan sebanyak 33 pertanyaan mengenai praktik pengelolaan aset desa. Terdapat empat jenis persepsi jawaban yang disiapkan dan dikelompokkan menjadi 4 (empat) jenis penilaian: pada penilaian 4 (empat) menggambarkan bahwa pernyataan sudah semuanya dilaksanakan, penilaian 3 (tiga) menggambarkan bahwa sudah sebagian besar dilakaksanakan, penilaian 2 (dua) menggambarkan bahwa sudah sebagian kecil dilaksanakan, dan penilaian 1 (satu) menggambarkan bahwa pernyataan belum sama sekali dilakukkan.

\section{Pengertian Mengenai Aset Desa}

Tabel 2

Pengertian Aset Desa

\begin{tabular}{clcc}
\hline No & & Responden & Rata-rata \\
\hline 1 & Aparatur Desa & 3,73 \\
2 & Inspektorat & 3,62 \\
\hline
\end{tabular}

Tabel di atas adalah tabel yang menggambarkan jawab responden mengenai pertanyaan pemahaman umum mengenai desa dan aset desa. Dari hasil perhitungan dapat terlihat bahwa jawaban tidak terpaut terlalu jauh hanya sebesar 0,11. Aparatur desa 
mendapat hasil sebesar 3,73 dan lebih tinggi sedikit daripada inspektorat yang hasilnya hanya sebesar 3,62. Dengan demikian dari pertanyaan tersebut dapat menunjukkan bahwa hampir semua responden yang berasal dari aparatur desa lebih paham, mengetahui, dan sudah melaksanakan pengertian dari desa dan aset desa dibandingkan dengan inspektorat.

\section{Pengertian Kepala Desa, Sekretaris Desa, Petugas Aset Desa Beserta Tanggung Jawab dan Wewenangnya.}

Tabel 3

Tanggung Jawab dan Wewenang Kepala Desa, Sekretaris, dan Petugas Aset Desa

\begin{tabular}{clc}
\hline No & Responden & Rata-rata \\
\hline 1 & Aparatur Desa & 3,46 \\
2 & Inspektorat & 3,46 \\
\hline
\end{tabular}

Tabel di atas adalah tabel yang menggambarkan jawab responden mengenai pertanyaan mengenai tugas, tanggung jawab serta wewenang dari kepala desa, sekretaris desa, dan petugas aset. Dari hasil perhitangan dapat terlihat bahwa jawaban memiliki hasil yang sama. Aparatur desa mendapat sebesar 3,46 dan inspektorat juga mendapatkan hasil sebesar 3,46 Dengan demikian dari pertanyaan tersebut dapat menunjukkan bahwa hampir semua responden yang berasal dari aparatur desa dan inspektorat paham dan mengetahui mengenai tugas, tanggung jawab serta wewenang dari kepala desa, sekretaris desa, dan petugas aset.

\section{Perencanaan}

Tabel 4

Perencanaan Aset Desa

\begin{tabular}{clc}
\hline No & Responden & Rata-rata \\
\hline 1 & Aparatur Desa & 3,42 \\
2 & Inspektorat & 3,58 \\
\hline
\end{tabular}

Tabel di atas adalah tabel yang menggambarkan jawab responden mengenai pertanyaan perencanaan kebutuhan aset desa. Dari hasil perhitungan dapat terlihat bahwa jawaban tidak terpaut terlalu jauh hanya sebesar 0,16. Inspektorat mendapat hasil sebesar 3,58 dan lebih tinggi sedikit daripada aparatur desa yang hasilnya hanya mendapat 
sebesar 3,42. Dengan demikian dari pertanyaan tersebut dapat menunjukkan bahwa hampir semua responden yang berasal dari Inspektorat lebih paham, mengetahui, dan sudah melaksanakan mengenai pertanyaan perencanaan kebutuhan aset desa dibandingkan dengan aparatur desa.

\section{Pengadaan}

Tabel 5

Pengadaan Aset Desa

\begin{tabular}{clc}
\hline No & Responden & Rata-rata \\
\hline 1 & Aparatur Desa & 3,35 \\
2 & Inspektorat & 3,27 \\
\hline
\end{tabular}

Tabel di atas adalah tabel yang menggambarkan jawab responden mengenai pertanyaan mengenai perinsip-perinsip yang digunakan dalam pengadaan aset. Dari hasil perhitungan dapat terlihat bahwa jawaban tidak terpaut terlalu jauh hanya sebesar 0,08. Aparatur desa mendapat hasil sebesar 3,35 dan lebih tinggi sedikit daripada inspektorat yang hasilnya hanya sebesar 3,27. Dengan demikian dari pertanyaan tersebut dapat menunjukkan bahwa hampir sebagian besar responden yang berasal dari aparatur desa lebih paham mengetahui, dan sudah melaksanakan perinsip-perinsip pengadaan aset desa dibandingkan dengan inspektorat.

\section{Penggunaan}

Tabel 6

Penggunaan Aset Desa

\begin{tabular}{clc}
\hline No & Responden & Rata-rata \\
\hline 1 & Aparatur Desa & 3,12 \\
2 & Inspektorat & 3,23 \\
\hline
\end{tabular}

Tabel di atas adalah tabel yang menggambarkan jawab responden mengenai pertanyaan penggunaan aset desa. Dari hasil perhitungan dapat terlihat bahwa jawaban tidak terpaut terlalu jauh hanya sebesar 0,11. Inspektorat menunjukkan hasil sebesar 3,23 dan lebih tinggi sedikit daripada aparatur desa yang hasilnya hanya sebesar 3,12. Dengan demikian dari pertanyaan tersebut dapat menunjukkan bahwa sebagian besar responden 
yang berasal dari Inspektorat lebih paham serta mengetahui mengenai penggunaan aset desa dibandingkan dengan aparatur desa.

\section{Pemanfaatan}

Tabel 7

Pemanfaatan Aset Desa

\begin{tabular}{clc}
\hline No & Responden & Rata-rata \\
\hline 1 & Aparatur Desa & 3,35 \\
2 & Inspektorat & 3,31 \\
\hline
\end{tabular}

Tabel di atas adalah tabel yang menggambarkan jawab responden mengenai pertanyaan mengenai bentuk pemanfaatan aset desa berupa sewa, pinjam pakai, kerjasama pemanfaatan bangun guna serah atau bangun serah guna. Dari hasil perhitungan dapat terlihat bahwa jawaban tidak terpaut terlalu jauh hanya sebesar 0,04. Aparatur desa menunjukkan hasil sebesar 3,35 dan lebih tinggi sedikit daripada inspektorat yang hanya mendapat 3,31. Dengan demikian dari pertanyaan tersebut dapat menunjukkan bahwa sebagian besar responden yang berasal dari aparatur desa lebih paham, mengetahui, dan sudah melaksanakan mengenai bentuk pemanfaatan aset desa berupa sewa, pinjam pakai, kerjasama pemanfaatan bangun guna serah atau bangun serah guna dibandingkan oleh inspektorat.

\section{Pengamanan}

Tabel 8

Pengamanan Aset Desa

\begin{tabular}{clc}
\hline No & \multicolumn{1}{c}{ Responden } & Rata-rata \\
\hline 1 & Aparatur Desa & 3,42 \\
2 & Inspektorat & 3,31 \\
\hline
\end{tabular}

Tabel di atas adalah tabel yang menggambarkan jawab responden mengenai pertanyaan mengenai pengamanan aset desa wajib dilakukan oleh kepala desa dan perangkat desa meliputi: administrasi, fisik, pengamanan fisik, penyimpanan dan pemeliharaan, pengamanan hukum. Dari hasil perhitungan dapat terlihat bahwa jawaban tidak terpaut terlalu jauh hanya sebesar 0,11. Aparatur desa menunjukkan hasil sebesar 3,42 dan lebih tinggi sedikit daripada inspektorat yang hasilnya hanya sebesar 3,31. 
Dengan demikian dari pertanyaan tersebut dapat menunjukkan bahwa sebagian besar responden yang berasal dari aparatur desa lebih paham dan mengetahui mengenai pengamanan aset desa wajib dilakukan oleh kepala desa dan perangkat desa meliputi: administrasi, fisik, pengamanan fisik, penyimpanan dan pemeliharaan, pengamanan hukum dibandingkan dengan inspektorat.

\section{Pemeliharaan}

Tabel 9

Pemeliharaan Aset Desa

\begin{tabular}{clc}
\hline No & \multicolumn{1}{c}{ Responden } & Rata-rata \\
\hline 1 & Aparatur Desa & 3,38 \\
2 & Inspektorat & 3,38 \\
\hline
\end{tabular}

Tabel di atas adalah tabel yang menggambarkan jawab responden mengenai pertanyaan mengenai seluruh biaya pemeliharaan aset desa dibebabkan pada APBDesa. Dari hasil perhitangan dapat terlihat bahwa jawaban menunjukkan hasil yang besarnya sama antara aparatur desa dengan inspektorat. Aparatur desa mendapat sebesar 3,38 dan sama dengan hasil yang didapat inspektorat seberat 3,38. Dengan demikian dari pertanyaan tersebut dapat menunjukkan bahwa sebagian besar responden yang berasal dari aparatur desa dan isnspektorat sama-sama paham dan mengetahui mengenai seluruh biaya pemeliharaan aset desa dibebabkan pada APBDesa.

\section{Penghapusan}

\section{Tabel 10}

Penghapusan Aset Desa

\begin{tabular}{|c|c|c|}
\hline No & Responden & Rata-rata \\
\hline 1 & Aparatur Desa & 3,15 \\
\hline 2 & Inspektorat & 3,42 \\
\hline
\end{tabular}

Tabel di atas adalah tabel yang menggambarkan jawab responden mengenai pertanyaan mengenai penyebab peghapusan aset desa dilakukan karena terjadinya: beralihnya kepemilikan, pemusnahan, kehilangan, kecurian dan kebakaran. Dari hasil perhitungan dapat terlihat bahwa jawaban tidak terpaut terlalu jauh hanya sebesar 0,27. Inspektorat menunjukkan hasil sebesar 3,42 dan lebih tinggi sedikit daripada aparatur 
desa yang hanya mendapatkan sebesar 3,15. Dengan demikian dari pertanyaan tersebut dapat menunjukkan bahwa sebagian besar responden yang berasal dari inspektorat lebih paham serta mengetahui mengenai peghapusan aset desa dilakukan karena terjadinya: beralihnya kepemilikan, pemusnahan, kehilangan, kecurian dan kebakaran dibandingkan dengan aparatur desa

\section{Pemindahtanganan}

Tabel 11

Pemindahtanganan Aset Desa

\begin{tabular}{clc}
\hline No & \multicolumn{1}{c}{ Responden } & Rata-rata \\
\hline 1 & Aparatur Desa & 3,19 \\
2 & Inspektorat & 3,50 \\
\hline
\end{tabular}

Tabel di atas adalah tabel yang menggambarkan jawab responden mengenai bentuk pemindahtanganan aset antara lain: tukar menukar, penjulan, dan penyertaan modal pemerintah desa. Dari hasil perhitungan dapat terlihat bahwa hasil jawaban tidak terpaut terlalu jauh hanya sebesar 0,31 . Inspektorat mendapat sebesar 3,50 dan lebih tinggi sedikit daripada aparatur desa yang hanya mendapatkan hasil sebesar 3,19. Dengan demikian dari pertanyaan tersebut dapat menunjukkan bahwa hampir semua responden yang berasal dari inspektorat lebih paham mengenai bentuk pemindahtanganan aset antara lain: tukar menukar, penjulan dan penyertaan modal pemerintah desa dibandingkan dengan aparatur desa.

\section{Penatausahaan}

Tabel 12

Penatausahaan Aset Desa

\begin{tabular}{clc}
\hline No & \multicolumn{1}{c}{ Responden } & Rata-rata \\
\hline 1 & Aparatur Desa & 3,15 \\
2 & Inspektorat & 3,35 \\
\hline
\end{tabular}

Tabel di atas adalah tabel yang menggambarkan jawab responden mengenai penerapan terhadap aset desa yang sudah ditetapkan pengunaannya harus diinventarisir dalam buku inventaris aset desa dengan diberi kodefikasi. Dari hasil perhitungan menunjukkan bahwa jawaban tidak terpaut terlalu jauh hanya sebesar 0,2. Inspektorat 
menunjukkan hasil sebesar 3,35 dan lebih tinggi sedikit daripada aparatur desa yang hanya mendapatkan hasil sebesar 3,15. Dengan demikian dari pertanyaan tersebut dapat menunjukkan bahwa sebagian besar responden yang berasal dari inspekrorat lebih paham mengenai penerapan terhadap aset desa yang sudah ditetapkan pengunaannya harus diinventarisir dalam buku inventaris aset desa dengan diberi kodefikasi dibandingkan dengan aparatur desa.

\section{Penilaian}

Tabel 13

Pengertian Mengenai Aset Desa

\begin{tabular}{clcc}
\hline No & & Responden & Rata-rata \\
\hline 1 & Aparatur Desa & 3,19 \\
2 & Inspektorat & 3,38 \\
\hline
\end{tabular}

Tabel di atas adalah tabel yang menggambarkan jawab responden mengenai inventarisasi dan penilaian aset desa sesuai ketentuan peraturan perundang-undangan dilakukan oleh Pemerintah Daerah Kabupaten/ Kota bersama Pemerintah desa. Dari hasil perhitungan dapat terlihat bahwa jawaban tidak terpaut terlalu jauh hanya sebesar 0,19. Inspektorat menunjukkan hasil sebesar 3,38 dan lebih tinggi sedikit daripada aparatur desa yang hanya mendaptkan hasil sebesar 3,19. Dengan demikian dari pertanyaan tersebut dapat menunjukkan bahwa sebagian besar responden yang berasal dari inspekrorat lebih paham mengenai inventarisasi dan penilaian aset desa sesuai ketentuan peraturan perundang-undangan dilakukan oleh Pemerintah Daerah Kabupaten/ Kota bersama Pemerintah desa. dibandingkan dengan aparatur desa.

Pembinaan dan Pengawasan

. Tabel 14

Pengertian Mengenai Aset Desa

\begin{tabular}{clcc}
\hline No & & Responden & Rata-rata \\
\hline 1 & Aparatur Desa & 3,33 \\
2 & Inspektorat & 3,46 \\
\hline
\end{tabular}

Tabel di atas adalah tabel yang menggambarkan jawab responden mengenai Bupati/ Walikota melakukan pembinaan dan pengawasan pengelolaan aset. Dari hasil 
perhitungan dapat terlihat bahwa jawaban tidak terpaut terlalu jauh hanya sebesar 0,13 . Inspektorat menunjukkan hasil sebesar 3,46 dan lebih tinggi sedikit daripada aparatur desa yang hanya mendapatkan sebesar 3,33. Dengan demikian dari pertanyaan tersebut dapat menunjukkan bahwa sebagian besar responden yang berasal dari inspekrorat lebih paham mengenai Bupati/ Walikota melakukan pembinaan dan pengawasan pengelolaan aset dibandingkan dengan aparatur desa.

\section{SIMPULAN}

Karakteristik responden dari 52 responden terdiri dari pelaksana sebagai aparatur desa dan inspektorat daerah selaku internal pemerintah daerah. Dari analisis karakteristik responden dapat menggambarkan bahwa tingkat pendidikan reponden terdiri dari SMA, S1, dan S2. Namun tingkat prosentase pendidikan responden terbanyak adalah S1. Dan untuk masa jabatan terbagi menjadi tiga yaitu: masa jabatan kurang dari 5 tahun, antara 510 tahun, dan yang terakhir adalah lebih dari 10 tahun. Jumlah responden dengan masa jabatan lebih dari 10 tahun terbanyak dengan hasil yang menunjukkan sebanyak 36 responden.

Analisis deskriptif dari 33 daftar pertanyaan dari beberapa pertanyaan kuesioner, responden banyak menganggap penting mengenai pengamanan aset desa, penatausahaan aset desa, dan pembinaan serta pengawasan terhadap aset desa. Jawaban yang telah diberikan oleh responden hampir $85 \%$ menjawab bahwa sudah semuanya melaksananakan pertanyaan yang berlaku baik dari inspektorat maupun dari aparatur desa. Hal ini menunjukkan bahwa kemungkinan pengelolaan keuangan desa terutama aset dapat berjalan sesaui dengan aturan yang telah ditetapkan. Hasil pengolahan data menggambarkan terdapat persamaan persepsi dan persamaan atas sesuatu hal mengenai apa yang dilakukan antara pelaksana (aparatur pemerintah desa) dengan inspektorat daerah selaku internal pemerintah daerah. Dengan tidak adanya perbedaan persepsi kecenderungan aturan yang berlaku dapat berhasil dengan baik dalam pelaksanaannya. Sehingga pelaksanaan dapat berjalan dengan baik dan diharapkan penyimpangan yang terjadi akan lebih sedikit terjadi. Berjalannya aturan yang ada terdapat hambatan utama yaitu mengenai sumber daya manusia. Namun terdapat pula faktor penghambat lain adalah mengenai kejelasan kepemilikan aset desa, pemeliharaan aset desa, dan pemanfaaatan aset desa. 


\section{REKOMENDASI}

Hasil dari karakrekteristik responden dari masa jabatan pelaksana dan inspektorat sebaiknya dilakukkan regenerasi. Regenerasi organisasi dilakukan agar adanya penerus untuk perwujudan tujuan organisasi yang harus selalu dipertahankan dan ditingkatkan di tiap generasinya. Sebuah regenerasi diadakan selalu dengan harapan untuk peningkatan yang lebih baik dari periode organisasi sebelumnya.

Permasalahan - permasalaahan tentunya yang sering terjadi. Untuk menghadapinya permasalahan lain yang terjadi mengenai kepemilikan aset, permasalahan sebaiknya harus segera diatasi dengan penatausahaan aset yang benar sesuai peraturan yang berlaku. Dengan demikian, sudah seharusnya aset desa dapat mendapat pengawasan yang lebih lagi. Persamaan persepsi antara pelaksana sebagai aparatur desa dengan inspektorat memepermudah berjalannya pelaksanaan pengelolaan desa terutama dalam pengelolaaan aset desa. Persamaan ini akan mempermudah dalam mengatasi permasalahan yang sedang atau mungkin terjadi. Karena tidak ada perbedaan persepsi, kecenderungan aturan yang ada dan sedang berlaku dapat berhasil dengan baik dalam pelaksanaannya, maka diharapkan penyimpangan yang terjadi akan lebih sedikit terjadi. Agar pesepsi dapat selalu berjalan sama perlu diadakan review secara berkala mengenai aturan yang berlaku, pengawasan dalam pelaksanaan peraturan yang berlaku, pemilihan sumber daya manusia yang benar-benar berkualitas, serta sering diadakannya pelatihan-pelatihan agar pelaksanaan dapat berjalan dengan baik dan lancar. 


\section{Daftar Pustaka}

Halim, Indra \&Soepriyanto, Gatot. 2002. ’Sistem Akuntansi Sektor Publik Konsep untuk pemerintah daerah". Jakarta: Salemba Empat.

Ghozali, Imam, 2011. Aplikasi Analisis Multivariate Dengan Program SPSS, Edisi Keempat, Penerbit Universitas Diponegoro.

Artikel mengenai Pengelolaan Keuangan Desa diakses online di http://www.bpkp.go.id /public/upload/unit/sakd/files/Juklakbimkonkeudesa.pdf. Diakses pada 18 April 2016.

Jawa Tengah online di https://id.wikipedia.org/wiki/Jawa_Tengah. Diakses 28 Mei 2016.

Panduan Pengelolaaa Keuanagan desa diakses online di http://www.bpkp.go.id/public/ upload/unit/sakd/files/Juklakbimkonkeudesa.pdf. Diakses tanggal 18 Mei 2016.

Penggunaan, Pengamanan dan Pemeliharaan BMD, online di http://bppk.depkeu.go.id /webpkn/images/ebook/Penggunaan_Pengamanan_dan Pemeliharaan_BMD/ ebooks/penggunaan-pengamanan-dan-pemeliharaaan bmd.pdf. Diakses pada 4 Mei 2016.

Peraturan pemerintah tentang Desa online di http://www.keuangandesa.com/wpcontent/uploads/2015/04/PP-No-72-Tahun-2005-Tentang-Desa.pdf. Diakses pada 5 April 2016.

Peraturan Pemerintahan tentan Peraturan Pelaksanaan Undang-undang Nomor 6 Tahun 2014 tentang desa, online di http://www.keuangandesa.com/wp-content luploads/2015/04/PP-No-43-Tahun-2014-Tentang Peraturan Pelaksanaan UndangUndang-Nomor-6-Tahun-2014-Tentang-Desa.pdf. Diakses pada 5 April 2016.

Peraturan Pemerintahan Nomor 47 Tahun 2015, online di http://www.keuangandesa.com /wp-content/uploads/2015/02/pp-47-2015.pdf . Diakses pada 5 April 2016.

Peraturan Pemerintah Nomor 58 Tahun 2005 tentang Pengelolaan keuangan Daerah online di http://hukum.unsrat.ac.id/pp/pp_58_05.htm. Diakses 12 Mei 2016.

Petunjuk Pelaksanaan Bimbingan \& Konsultasi Pengelolaan Keuangan Desa, http://www.bpkp.go.id/public/upload/unit/sakd/files/Juklakbimkonkeudesa.pdf. Diakses pada 12 Mei 2016

Tata Cara Pengalokasian, Penyaluran, Penggunaan, Pemantauan, dan Evaluasi Dana Desa, online di http://jogloabang.com/pustaka/tata-cara-pengalokasian-penyaluranpenggunaan-pemantauan-dan-evaluasi-dana-desa. Diakses 13 Mei 2016.

Undang-undang tentang Pengelolaan Aset Desa. Terdapat online di http:// www.keuangandesa.com/wp-content/uploads/2016/04/Permendagri-Nomor-01Tahun-2016-Pengelolaan-Aset-Desa.pdf. Diakses pada 5 April 2016.

Undang-undang yang mengatur tentang Desa. Terdapat online Di http: //www.keuangandesa.com/wp-content/uploads/2015/04/UU-No-6-Tahun-2014Tentang-Desa.pdf. Diakses pada 5 April 2016. 